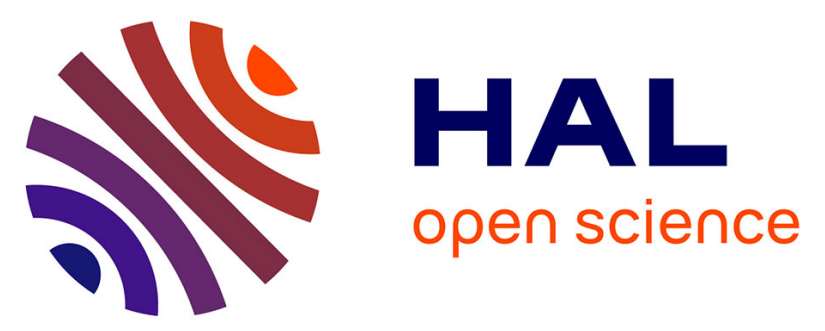

\title{
Evaluation of best corrected visual acuity and central macular thickness after intravitreal dexamethasone implant injections in patients with Irvine-Gass syndrome: a retrospective study of six cases
}

Chafik Keilani, Aziz Halalchi, Désiré Wakpi Djeugue, Anne Regis, Samir Abada

\section{To cite this version:}

Chafik Keilani, Aziz Halalchi, Désiré Wakpi Djeugue, Anne Regis, Samir Abada. Evaluation of best corrected visual acuity and central macular thickness after intravitreal dexamethasone implant injections in patients with Irvine-Gass syndrome: a retrospective study of six cases. Thérapie, 2016, 10.1016/j.therap.2016.01.009 . hal-01310385

\section{HAL Id: hal-01310385 \\ https://hal.sorbonne-universite.fr/hal-01310385}

Submitted on 2 May 2016

HAL is a multi-disciplinary open access archive for the deposit and dissemination of scientific research documents, whether they are published or not. The documents may come from teaching and research institutions in France or abroad, or from public or private research centers.
L'archive ouverte pluridisciplinaire HAL, est destinée au dépôt et à la diffusion de documents scientifiques de niveau recherche, publiés ou non, émanant des établissements d'enseignement et de recherche français ou étrangers, des laboratoires publics ou privés. 
EVALUATION OF BEST CORRECTED VISUAL ACUITY AND CENTRAL

MACULAR THICKNESS AFTER INTRAVITREAL DEXAMETHASONE IMPLANT

INJECTIONS IN PATIENTS WITH IRVINE-GASS SYNDROME : A

RETROSPECTIVE STUDY OF SIX CASES

ÉVALUATION DE LA MEILLEURE ACUITÉ VISUELLE CORRIGÉE ET DE L'ÉPAISSEUR MACULAIRE CENTRALE APRES INJECTIONS INTRA VITRÉENNES D'UN IMPLANT DE DEXAMÉTHASONE CHEZ DES PATIENTS ATTEINTS D'UN SYNDROME D'IRVINE GASS : UNE ÉTUDE

\section{RÉTROSPECTIVE SUR 6 CAS}

Chafik KEILANI (1), Aziz HALALCHI (2), Désiré WAKPI DJEUGUE (2), Anne REGIS

(2), Samir ABADA (2)

(1) Department of vascular neurology, hôpital universitaire de la Pitié-Salpêtrière.

Faculty of medicine Pierre et Marie Curie (Paris VI).

Address : 47-83 Boulevard de l'Hôpital, 75013 Paris, France.

Tel : +33142163493

Fax : +33142162860

Mail : chafik.keilani@aphp.fr; chafik.keilani@etu.upmc.fr; chafk.keilani@gmail.com

(2) Department of ophthalmology, hôpital François Quesnay, 2 boulevard Sully, 78201 Mantes-la-Jolie CEDEX, France.

Tel : +33134974100

Fax : +33134974176

Mail : cs.extoph-sto@ch-mantes.fr 


\section{ABSTRACT}

PURPOSE. Irvine-Gass syndrome is a macular edema (ME) that specifically occur after cataract surgery. Its incidence varies from $0,2-2 \%$. The purpose of this study is to evaluate the effectiveness of intravitreal dexamethasone implant injections in patients with Irvine-Gass syndrome.

METHODS. Patients with ME secondary to cataract surgery who underwent intravitreal injections of dexamethasone implant between December 2011 to October 2014 at François Quesnay hospital (Mantes-la-Jolie, France) were retrospectively reviewed. The patients were followed for at least 10 months. All the patients were handled by intravitreal injection of dexamethasone in the eye of study among which some resisted to a preliminary treatment by nonsteroidal anti-inflammatory drug (NSAID) and acetazolamide. The patients were examined each month. The patients were again handled by intravitreal injection of dexamethasone if they presented a recurrence. The primary endpoint of the study was determined on best corrected visual acuity (BCVA) using early treatment diabetic retinopathy study (ETDRS) scale and central macular thickness $(\mathrm{CMT})(\mu \mathrm{m})$ using optical coherence tomography (OCT) 3 and 6 months after the first injection. Secondary endpoints were the number of recurrences, the number of injections, the duration average before the first recurrence, the BCVA 10 months after the first injection and the tolerance.

RESULTS. Six eyes of six patients were studied. At baseline, the mean (Standard Deviation, SD) of the BCVA was 59,8 \pm 11 . Three months after the first injection, the mean (SD) of the BCVA showed a statistically significant increase to $72,2 \pm 8,6(p=0,03)$. Six months after the first injection, the mean (SD) of the BCVA showed a statistically significant increase to $72 \pm$ $11,8(\mathrm{p}=0,03)$. Concerning the CMT, the mean (SD) was 495,6 $\pm 135,2$ before treatment. Three months after the first injection, the mean (SD) of the CMT showed a statistically 
significant decrease to $268,6 \pm 57,8$ ( $\mathrm{p}=0,03$ ). Six months after the first injection, the mean (SD) of the CMT showed a decrease to $350,1 \pm 56,3(\mathrm{p}=0,09)$.

CONCLUSION. In this study, both mean BCVA and mean CMT had significantly improved from baseline after treatment with dexamethasone implant in patients with Irvine-Gass syndrome.

Key-words : Postsurgical cystoid macular edema; optical coherence tomography; acetazolamide; non-steroidal anti-inflammatory; intravitral dexamethasone implant. 


\section{RESUME}

OBJECTIF. Le syndrome d'Irvine Gass encore appelé œdème maculaire (OM) postopératoire est la cause la plus fréquente de baisse d'acuité visuelle (AV) après chirurgie de la cataracte. Son incidence varie de $0,2 \%$ à $2 \%$. Le but de cette étude est d'évaluer l'efficacité d'injections intravitréennes d'un implant de dexaméthasone chez des patients atteints d'un syndrome d'Irvine Gass.

METHODES. Les patients présentant un œdème maculaire secondaire à une chirurgie de la cataracte et ayant eu des injections intravitréennes d'un l'implant de dexaméthasone à l'hôpital François Quesnay (Mantes-la-Jolie, France) de décembre 2011 à octobre 2014 ont été étudiés de manière rétrospective. Tous les patients ont reçu un implant de dexaméthasone dans l'œil d'étude dont certains étaient réfractaires à un traitement préalable par anti-inflammatoires non stéroïdiens (AINS) et acétazolamide. Les patients ont été suivis pendant au moins 10 mois et examinés de manière mensuelle. Les patients étaient de nouveau traités par injection intravitréenne de dexaméthasone s'ils présentaient une récidive. Le critère de jugement principal était l'amélioration de la meilleure acuité visuelle corrigée (MAVC) sur l'échelle Early Treatment Diabetic Retinopathy Study (ETDRS) et la régression de l'OM mesuré par l'épaisseur maculaire centrale (EMC) $(\mu \mathrm{m})$ sur la Tomographie en Cohérence Optique (OCT) à 3 mois et 6 mois. Les critères de jugement secondaires étaient le nombre de récidives, le nombre d'injections, la durée moyenne avant la première récidive, la MAVC à 10 mois et la tolérance.

RÉSULTATS. Six yeux de six patients ont été étudiés. Avant traitement, la moyenne (écarttype, ET) de la MAVC était de 59,8 \pm 11 . Trois mois, après la première injection, la moyenne (ET) de la MAVC a augmenté de manière statistiquement significative à 72,2 $\pm 8,6(\mathrm{p}=0,03)$. Six mois après la première injection, la moyenne (ET) de la MAVC a augmenté de manière 
statistiquement significative à $72 \pm 11,8(\mathrm{p}=0,03)$. Concernant l'EMC, la moyenne (ET) était de 495,6 \pm 135,2 avant traitement. Trois mois après la première injection, la moyenne (ET) de l'EMC a diminué de manière statistiquement significative à 268,6 $\pm 57,8(\mathrm{p}=0,03)$. Six mois, après la première injection, la moyenne (ET) de l'EMC a diminué de manière non statistiquement significative à $350,1 \pm 56,3(\mathrm{p}=0,09)$.

CONCLUSION. Dans cette étude, la MAVC et l'EMC ont été significativement améliorées après traitement par injections intravitéennes de dexaméthasone chez des patients ayant un syndrome d'Irvine Gass dont certains étaient résistants au traitement conventionnel par AINS et acétazolamide.

Mots clés : œdème maculaire postopératoire; tomographie en cohérence optique; acétazolamide; anti-inflammatoires non stéroïdiens; implant intravitréen de dexaméthasone 


\section{INTRODUCTION}

Irvine-Gass syndrome is a macular edema (ME) that specifically occur after cataract surgery. It is also called postoperative pseudophakic ME. It has been reported for the first time in 1953 by Irvine Gass then in 1966 on angiographic descriptions [1,2]. . Irvine-Gass syndrome is recognized as a common causes of poor visual outcome following cataract surgery. Its incidence varies from $0,2 \%$ to $2 \%$ [3]. However, this is probably underestimated because in 9 to $20 \%$, asymptomatic transient edema is detected on angiography and on optical coherence tomography (OCT). 60 to $70 \%$ of postoperative ME regress after a period of several months and 3\% of them become chronic. [4] The pathogenesis of postoperative ME is uncertain and probably multifactorial. However, the main source appears to be inflammatory. The surgery promotes activation of phospholipase A2, and the synthesis of prostaglandins, leukotrienes and platelet activating factor (PAF) [5]. Prostaglandins cause a disruption of the blood-retinal barrier which would increase its permeability with fluid retention in the retina. The effectiveness of anti-inflammatory treatments in Irvine-Gass syndrome and induction of ME by prostaglandin analogues are consistent with this hypothesis [6,7].

Current therapeutic options in Irvine-Gass syndrome such anti-inflammatory drugs (NSAIDs) and acetazolamide, are not enough in some cases that are called refractory postoperative ME $[8,9]$. The use of intravitreal injections of anti-vascular endothelial growth factor (antiVEGF) has been reported by some authors but without convincing results. In this context, the use of intravitreal injections of dexamethasone implant seems interesting. Dexamethasone is a glucocorticoid inhibition of phospholipase A2 and it could have an important place in the treatment of postoperative ME. 
The main objective of this study is to evaluate the effectiveness of intravitreal injections of dexamethasone implant in patients with ME secondary to cataract surgery.

\section{PATIENTS AND METHODS}

We retrospectively reviewed the medical records of six patients with visual acuity (VA) secondarily reduced to Irvine-Gass syndrome who received injections of dexamethasone implant of Ozurdex® (Allergan, Inc., Irvine, CA) between December 2011 and October 2014 in the department of ophthalmology of François Quesnay hospital at Mantes-la-Jolie (France). The main inclusion criterion was the presence of Irvine Gass syndrome with declined VA with resistance to a wide range of treatment options including oral inhibitors of carbonic anhydrase, a combination product of topical NSAIDs with eye drops or anti-VEGF injections. The diagnosis of Irvine Gass syndrome was established by the identification of postoperative cystoid ME on the retina funduscopic examination and on the optical coherence tomography (OCT) and the fluorescein angiography. The decline in VA was assessed by the Early Treatment Diabetic Retinopathy Scale Study (ETDRS). Refractory ME was defined by the persistence of foveal thickness of more than 250 microns in the spectral domain OCT for a period of at least 90 days of treatment with NSAIDs, acetazolamide and / or anti VEGF. Exclusion criteria were untreated and uncontrolled chronic glaucoma, diabetes with retinopathy or diabetic maculopathy, periocular or ocular active infection, the diagnosis of uncontrolled systemic disease, epiretinal membrane, macular vitreoretinal traction syndrome that could prevent the improvement of VA, and laser therapy in the eye of study in the previous 3 months. 
Before treatment, all patients underwent complete ophthalmologic evaluation including fundoscopic examination, an assessment of best corrected visual acuity (BCVA) according to standardized ETDRS scale, tonometry, an OCT (Heidelberg Engineering Spectralis ®, Spectral Domain OCT), a fluorescein angiography. The patients received dexamethasone implant (700 microns) in the eye of study after the initial visit. A disposable applicator with a needle was used to inject the dexamethasone implant in the vitreous. All injections were performed according to the recommendations set by French Health Authority (HAS) and the pharmaceutical company marketing the dexamethasone implant. All patients were examined monthly after the first injection for a minimum of 10 months. A complete eye examination similar to that performed before treatment was done. The patients were again treated with dexamethasone intravitreal injection if they had a recurrence. Recurrence was defined by the loss of one line on the ETDRS scale compared to the previous BCVA and recurrence of ME on OCT measured by the central macular thickness (CMT) (in nm). Informed consent of all patients was obtained before treatment.

The primary endpoint was improvement in BCVA on the ETDRS scale and regression of cystoid ME measured by the CMT at 3 months and 6 months. The secondary outcomes were the number of relapses, the number of injections, the mean time to the first recurrence, BCVA at 10 months and tolerance.

$\mathrm{P}$ values for the analysis of the primary endpoint were obtained using the test of Wilcoxon signed rank, with $\mathrm{p}<0.05$ considered statistically significant.

\section{RESULTS}

Six eyes of six patients were included. Analysis of the patients characteristics (Table 1) showed that the average time between the surgery and diagnosis was $6,33 \pm 5,08$ weeks (mean 
\pm standard deviation). The average age was $77,8 \pm 4,4$ years. The sex ratio was $1: 1$. One patient had a history of glaucoma treated and well balanced. Among the eyes included, four were refractory to topical NSAID treatment and acetazolamide. One had in addition to topical NSAID and acetazolamide, anti-VEGF. None of the eyes had complication during surgery.

Before treatment, the mean (standard deviation, SD) of BCVA was $59.8 \pm 11$. Three months after the first injection, the mean (SD) of the BCVA increased statistically significantly $72.2 \pm$ $8.6(\mathrm{p}=0,03)$. Six months after the first injection, the mean (SD) of the BCVA increased statistically significantly to $72.2 \pm 8.6(\mathrm{p}=0.03)$ (Table 2$)$. Regarding CMT, the mean $(\mathrm{SD})$ was $495.6 \pm 135.2$ before treatment. Three months after the first injection, the mean (SD) of the CMT decreased statistically significantly to $268.6 \pm 57.8(\mathrm{p}=0.03)$ (Figure 1 and 2). Six months after the first injection, the mean (SD) of the CMT decreased to $350.1 \pm 56.3$ ( $\mathrm{p}=$ 0.09) (Table 2).

Four patients relapsed after the first injection : 66.6\% of the study population (Table 3, 4 and $5)$.

Mean (SD) of intravitreal injections of dexamethasone was 2,16 $\pm 0,98$ during 10 months. Mean (SD) before the first recurrence was 3,6 3,5 months. Regarding tolerance, half of the study population developed ocular hypertension that regressed after initiation of topical hypotonic treatment. No cases of endophthalmitis were highlighted.

\section{DISCUSSION}

In this study, intravitreal injection of dexamethasone implant appears to be effective at 3 and 6 months in patients with Irvine-Gass syndrome. We noted a statistically significant improvement in BVCA and CMT at 3 months. 
In our study the incidence of postoperative CMT is lower than in other studies. However, this variation can be explained by the influence of many risk factors such as the duration of surgery, the existence of intraoperative complications, diabetes, use of prostaglandins... . The duration of 10 months follow-up is less than some studies where it is around 12 months. Beyond this period, we found that monitoring was difficult because many patients were lost to follow-up.

Most studies have evaluated the effectiveness of acetazolamide associated with NSAIDs in postoperative ME. They have demonstrated the effectiveness of the combination of these two treatments [10]. But there are many patients who remain refractory patients.

There are few studies that have evaluated the efficacy of intravitreal injection of dexamethasone implant on Irvine Gass syndrome. Our results at 3 months after the first intravitreal dexamethasone consistent with those obtained in studies of Dutra Medeiros and al. [11], of Kodjikian and al. [12] and EPISODIC.

Regarding the pathophysiology, corticosteroids block the release of arachidonic acid and thus the inflammatory cascade that would be the main mechanism involved in Irvine-Gass syndrome. Corticosteroids also act on interleukins and VEGF. Corticosteroids favor the resorption of the ME. Other authors such as Benhamou et al. [13] attempted intravitreal injections of triamcinolone with success. But there is in this corticosteroid treatment side effects like intraocular hypertension. Moreover, recurrences were frequent with triamcinolone.

Others have tried intravitreal injections of anti-VEGF but without success. 
Thus, the intravitreal dexamethasone appears to be an interesting therapeutic in 1 st or 2 nd intent in Irvine Gass syndrome. The study showed a recurrence rate of $66.6 \%$ with dexamethasone treatment. None of the patients showed resistance to treatment. There is probably a dependence on steroids because all patients with recurrence responded again to treatment. Compared to the side effects, one patient had an ischemic stroke. This event does not seem related to the initiation of treatment. $66.6 \%$ of patients had an intraocular pressure which fell after initiation of treatment with $\beta$-blocker contrast to triamcinolone. No prostaglandin has been delivered because this treatment is recognized as a risk factor of Irvine-Gass syndrome. This percentage may seem high but dexamethasone implant is known to be provider of intraocular hypertension.

Moreover, it does not seem to be any correlation between the functional and anatomical result since some patients had improvement of VA without cystoid ME improvement. Indeed, at 6 months after the first injection some patients had stable VA with an increase of cystoid ME (Figure 1 and 2).

Intravitreal injection of dexamethasone implant seems effective in Irvine-Gass syndrome. An interventional study is needed to confirm these results.

\section{ACKNOWLEDGMENTS}

H. KEILANI,

S. EVEILLARD, N. JOUZIER, C. REGNAT.

\section{Declaration of interests}


The authors declare that they have no conflicts of interest related to this article.

\section{REFERENCES}

[1] Irvine S.R. A newly defined vitreous syndrome following cataract surgery Am $J$ Ophthalmol $1953 ; 36$ : 599-619.

[2] Gass J.D., Norton E.W. Cystoid macular edema and papilledema following cataract extraction: a fluorescein fundoscopic and angiographic study. 1996 Retina 2003 ; 23 (Suppl. 6) : 646-661.

[3] Connor TB, Pulido JS. Management of aphakic and pseudophakic cystoid macular edema. Curr Opin Ophtalmol, 1993;4:90-101.

[4] Yonekawa Y., Kim I.K. Pseudophakic cystoid macular edema Curr Opin Ophthalmol $2012 ; 23: 26-32$.

[5] Miyake K., Ibaraki N. Prostaglandins and cystoid macular edema Surv Ophthalmol 2002 ; 47 (Suppl. 1) : S203-S218.

[6] Flach A.J., Stegman R.C., Graham J., Kruger L.P. Prophylaxis of aphakic cystoid macular edema without corticosteroids. A paired-comparison, placebo-controlled double-masked study Ophthalmology $1990 ; 97: 1253-1258$.

[7] Miyake K., Ota I., Maekubo K., Ichihashi S., Miyake S. Latanoprost accelerates disruption of the blood aqueous barrier and the incidence of angiographic cystoid macular edema in early postoperativepseudophakias Arch Ophthalmol 1999 ; 117 : 34-40

[8] Shelsta HN, Jampol LM. Pharmacologic therapy of pseudophakic cystoid macular edema: 2010 update. Retina. 2011;31:4-12.

[9] Sivaprasad S, Bunce C, Wormland R. Non-steroidal antiinflammatory agents for cystoid macular edema following cataract surgery: a systematic review. $\mathrm{Br}$ J Ophthalmol. 2005; 89:1420-1422. 
[10] A. Catier, R. Tayadoni, P. Massin, A. Gaudric Intérêt de l'acétazolamide associé aux anti-inflammatoires dans le traitement de l'œdème maculaire postopératoire $J F O, 2005 ; 28$, $10,1027-1031$

[11] Dutra Medeiros et al. Dexamethasone Intravitreal Implant for Treatment of Patients With Recalcitrant Macular Edema Resulting From Irvine-Gass Syndrome IOVS journal May 2013; $54-3324$

[12] Bellocq D, Kodjikian L. Intérêt de l'implant de dexaméthasone dans le traitement du syndrome d'Irvine Gass Les cahiers d'ophtalmologie Numéro 172 - Septembre 2013

[13] Benhamou N, Massin P, Haouchine B. Intravitreal triamcinolone for refractory pseudophakic macular edema. Am J Ophthalmol. 2003;135:246-249. 
Tables:

Table 1 : Characteristics of the study population

Table 2: Primary outcome at 3 months and 6 months

Table 3: Monitoring BCVA (ETDRS score)

Table 4: Monitoring CMT

Table 5: Secondary endpoints 


\section{TABLES}

Table 1 : Characteristics of the study population

\begin{tabular}{|l|c|}
\hline $\begin{array}{l}\text { Number of patients refractory to treatment with NSAIDs and } \\
\text { Acetazolamide treated with dexamethasone intravitreal injection }\end{array}$ & 3 \\
\hline $\begin{array}{l}\text { Number of patients refractory to treatment with NSAIDs and } \\
\text { anti-VEGF, acetazolamide treated with dexamethasone } \\
\text { intravitreal injection }\end{array}$ & 2 \\
\hline $\begin{array}{l}\text { Number of patients treated only by dexamethasone intravitreal } \\
\text { injection }\end{array}$ & $77,8 \pm 4,4^{\circ}$ \\
\hline Age (years) & $50 / 50^{*}$ \\
\hline Female / male (\%) & $6,33 \pm 5,08^{\circ}$ \\
\hline Time between the intervention and diagnosis (weeks) & $66,6 / 33,3^{*}$ \\
\hline Right / left eye (\%) & \\
\hline
\end{tabular}

${ }^{\circ}$ The more or less correspond to mean values +/- standard deviation

* Percentages are rounded, it do not always lead to a total of 100

Table 2 : Primary outcome at 3 months and 6 months

\begin{tabular}{|c|c|c|c|c|c|}
\hline & $\begin{array}{c}\text { Pretreatment } \\
\text { values }\end{array}$ & $\begin{array}{c}\text { Values 3 } \\
\text { months after } \\
\text { the first } \\
\text { injection }\end{array}$ & $\mathrm{p}$ values & $\begin{array}{c}\text { Values 6 } \\
\text { months after } \\
\text { the first } \\
\text { injection }\end{array}$ & $\mathrm{p}$ values \\
\hline $\begin{array}{c}\text { BVAC } \\
\text { (ETDRS } \\
\text { score) }\end{array}$ & $59,8 \pm 11^{\circ}$ & $72,2 \pm 8,6^{\circ}$ & $\mathrm{P}=0,03^{*}$ & $72 \pm 11,8^{\circ}$ & $\mathrm{P}=0,03^{*}$ \\
\hline CMT & $495,6 \pm 135,2^{\circ}$ & $268,6 \pm 57,8^{\circ}$ & $\mathrm{P}=0,03^{*}$ & $350,1 \pm 56,3^{\circ}$ & $\mathrm{P}=0,09$ \\
\hline
\end{tabular}

${ }^{\circ}$ The more or less correspond to mean values $+/$ - standard deviation

* Statistically significant result $\mathrm{p}<0.05$ 
Table 3 : Monitoring BCVA (ETDRS score)

\begin{tabular}{|c|c|c|c|c|c|c|c|c|c|c|c|}
\hline $\begin{array}{l}\text { Pati } \\
\text { ent }\end{array}$ & $\begin{array}{c}\text { Initial } \\
\text { BVA } \\
\text { C } \\
\text { before } \\
\text { treatm } \\
\text { ent }\end{array}$ & $\begin{array}{c}\text { BVA } \\
\text { C } 1 \\
\text { mont } \\
\text { h } \\
\text { after } \\
\text { first } \\
\text { inject } \\
\text { ion }\end{array}$ & $\begin{array}{c}\text { BVA } \\
\text { C } 2 \\
\text { mont } \\
\text { h } \\
\text { after } \\
\text { first } \\
\text { inject } \\
\text { ion }\end{array}$ & $\begin{array}{c}\text { BVA } \\
\text { C } 3 \\
\text { mont } \\
\mathrm{h} \\
\text { after } \\
\text { first } \\
\text { inject } \\
\text { ion }\end{array}$ & $\begin{array}{c}\text { BVA } \\
\text { C } 4 \\
\text { mont } \\
\text { h } \\
\text { after } \\
\text { first } \\
\text { inject } \\
\text { ion }\end{array}$ & $\begin{array}{c}\text { BVA } \\
\text { C } 5 \\
\text { mont } \\
\text { h } \\
\text { after } \\
\text { first } \\
\text { inject } \\
\text { ion }\end{array}$ & $\begin{array}{c}\text { BVA } \\
\text { C } 6 \\
\text { mont } \\
\text { h } \\
\text { after } \\
\text { first } \\
\text { inject } \\
\text { ion }\end{array}$ & $\begin{array}{c}\text { BVA } \\
\text { C } 7 \\
\text { mont } \\
\text { h } \\
\text { after } \\
\text { first } \\
\text { inject } \\
\text { ion }\end{array}$ & $\begin{array}{c}\text { BVA } \\
\text { C } 8 \\
\text { mont } \\
\text { h } \\
\text { after } \\
\text { first } \\
\text { inject } \\
\text { ion }\end{array}$ & $\begin{array}{c}\text { BVA } \\
\text { C } 9 \\
\text { mont } \\
\text { h } \\
\text { after } \\
\text { first } \\
\text { inject } \\
\text { ion }\end{array}$ & $\begin{array}{c}\text { BVA } \\
\text { C } 10 \\
\text { mont } \\
\text { h } \\
\text { after } \\
\text { first } \\
\text { inject } \\
\text { ion }\end{array}$ \\
\hline $1 \dagger$ & 49 & 58 & 56 & 58 & 54 & $52^{\circ *}$ & 52 & 52 & 58 & 63 & $57^{\circ}$ \\
\hline $2 \dagger$ & 67 & 77 & 75 & 77 & 77 & 77 & 77 & - & - & - & - \\
\hline 3 & 56 & 60 & 60 & $73^{\circ *}$ & 75 & - & 78 & - & - & 78 & $64^{\circ}$ \\
\hline $4 \uparrow$ & 50 & 64 & 64 & 70 & 59 & $50^{\circ}$ & $63^{*}$ & 64 & 69 & 64 & $57^{\circ *}$ \\
\hline $5 \dagger$ & 78 & 84 & 81 & 84 & - & - & 82 & - & 85 & - & 85 \\
\hline 6 & 59 & 71 & 75 & 79 & 78 & - & 80 & 79 & 75 & $72^{\circ}$ & 68* \\
\hline
\end{tabular}

$\dagger$ Patients who were refractory to a wide range of treatment options including oral inhibitors of carbonic anhydrase, a topical combination therapy with NSAIDs eye drops or even anti-

VEGF injections

${ }^{\circ}$ Recurrence

* New intravitreal injection of dexamethasone

- Missing (patients who didn't go to their medical consultation)

Tableau 4 : Monitoring CMT

\begin{tabular}{|c|c|c|c|c|c|c|c|c|c|c|c|}
\hline $\begin{array}{c}\text { Pat } \\
\text { ien } \\
\mathrm{t}\end{array}$ & $\begin{array}{c}\text { Initial } \\
\text { CMT } \\
\text { before } \\
\text { treatme } \\
\text { nt }\end{array}$ & $\begin{array}{c}\text { CMT } \\
1 \\
\text { mont } \\
\mathrm{h} \\
\text { after } \\
\text { first } \\
\text { inject } \\
\text { ion }\end{array}$ & $\begin{array}{c}\text { CMT } \\
2 \\
\text { mont } \\
\mathrm{h} \\
\text { after } \\
\text { first } \\
\text { inject } \\
\text { ion }\end{array}$ & $\begin{array}{c}\text { CMT } \\
3 \\
\text { month } \\
\text { after } \\
\text { first } \\
\text { injecti } \\
\text { on }\end{array}$ & $\begin{array}{c}\text { CMT } \\
4 \\
\text { month } \\
\text { after } \\
\text { first } \\
\text { injecti } \\
\text { on }\end{array}$ & $\begin{array}{c}\text { CMT } \\
5 \\
\text { month } \\
\text { after } \\
\text { first } \\
\text { injecti } \\
\text { on }\end{array}$ & $\begin{array}{c}\text { CMT } \\
6 \\
\text { month } \\
\text { after } \\
\text { first } \\
\text { injecti } \\
\text { on }\end{array}$ & $\begin{array}{c}\text { CMT } \\
7 \\
\text { month } \\
\text { after } \\
\text { first } \\
\text { injecti } \\
\text { on }\end{array}$ & $\begin{array}{c}\text { CMT } \\
8 \\
\text { month } \\
\text { after } \\
\text { first } \\
\text { injecti } \\
\text { on }\end{array}$ & $\begin{array}{c}\text { CMT } \\
9 \\
\text { month } \\
\text { after } \\
\text { first } \\
\text { injecti } \\
\text { on }\end{array}$ & $\begin{array}{c}\text { CMT } \\
10 \\
\text { month } \\
\text { after } \\
\text { first } \\
\text { injecti } \\
\text { on }\end{array}$ \\
\hline $1 \dagger$ & 558 & 218 & 191 & 184 & 479 & $479^{\circ} *$ & 330 & 224 & 181 & 180 & $255^{\circ}$ \\
\hline $2 \dagger$ & 251 & 216 & 213 & 213 & 226 & 397 & 390 & - & - & 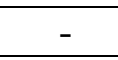 & ${ }^{-}$ \\
\hline 3 & 460 & 266 & 251 & $359^{\circ} *$ & 438 & - & 430 & - & - & 473 & $444^{\circ}$ \\
\hline $4 \dagger$ & 579 & 357 & 349 & 339 & 372 & $328^{\circ}$ & $370^{*}$ & 356 & 343 & 358 & $424^{\circ} *$ \\
\hline $5 \dagger$ & 491 & 236 & 222 & 235 & - & - & 292 & - & 242 & - & 240 \\
\hline 6 & 635 & 319 & 282 & 276 & 288 & - & 289 & 291 & 305 & $300^{\circ}$ & $298^{*}$ \\
\hline
\end{tabular}

$\dagger$ Patients who were refractory to a wide range of treatment options including oral inhibitors of carbonic anhydrase, a topical combination therapy with NSAIDs eye drops or even anti-

VEGF injections

${ }^{\circ}$ Recurrence

* New intravitreal injection of dexamethasone

- Missing (patients who didn't go to their medical consultation) 
Tableau 5 : Secondary endpoints

\begin{tabular}{|l|c|}
\hline Percentage of patients who relapsed $(\%)$ & 66.6 \\
\hline $\begin{array}{l}\text { Average number of dexamethasone } \\
\text { intravitreal injections }\end{array}$ & $2,16 \pm 0.98^{\circ}$ \\
\hline Mean time to first recurrence (months) & $3.6 \pm 3.5^{\circ}$ \\
\hline BCVA at 10 months $\dagger$ & $66.2 \pm 11.5^{\circ}$ \\
\hline
\end{tabular}

${ }^{\circ}$ The more or less correspond to mean values +/- standard deviation

$\uparrow$ The average BCVA at 10 months was calculated out of 5 patients because the patient 2 was followed for 6 months 


\section{Figures}

Figure 1. Patient 1: macular OCT, 3 months, 5 months and 6 months after the first injection

Figure 2. Patient 5: macular OCT, 3 months and 6 months after the first injection 
FIGURES

Figure 1. Patient 1: macular OCT diagnosis, 3 months, 5 months and 6 months after the first injection

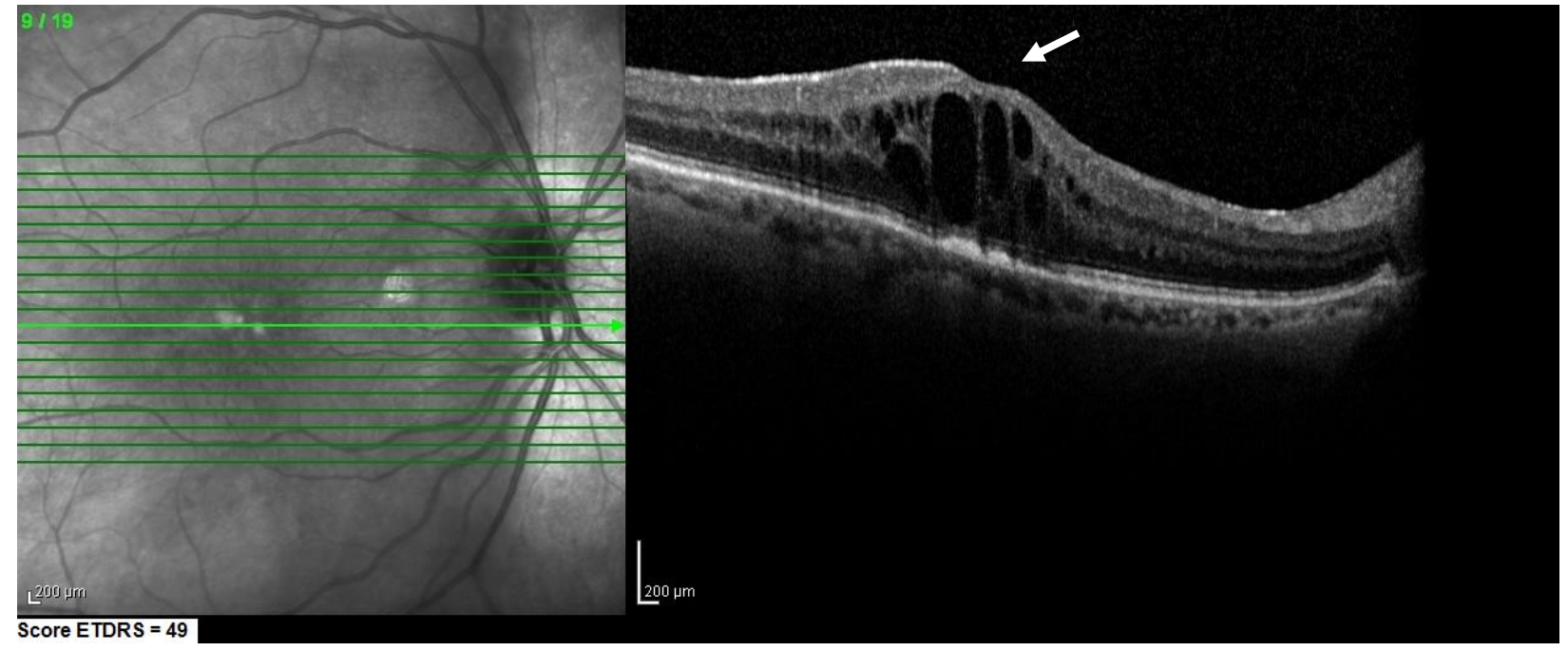

\section{OCT at diagnosis}

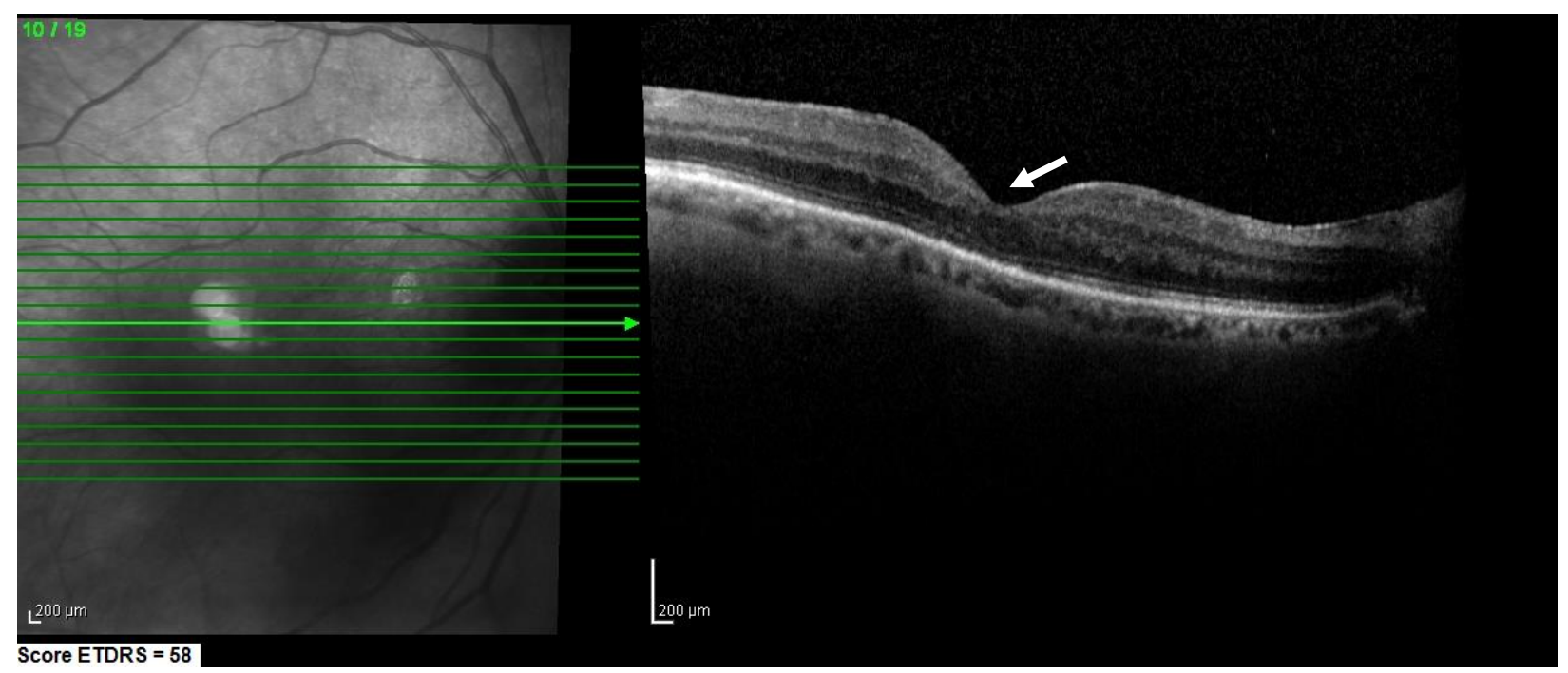

OCT 3 months after first injection 


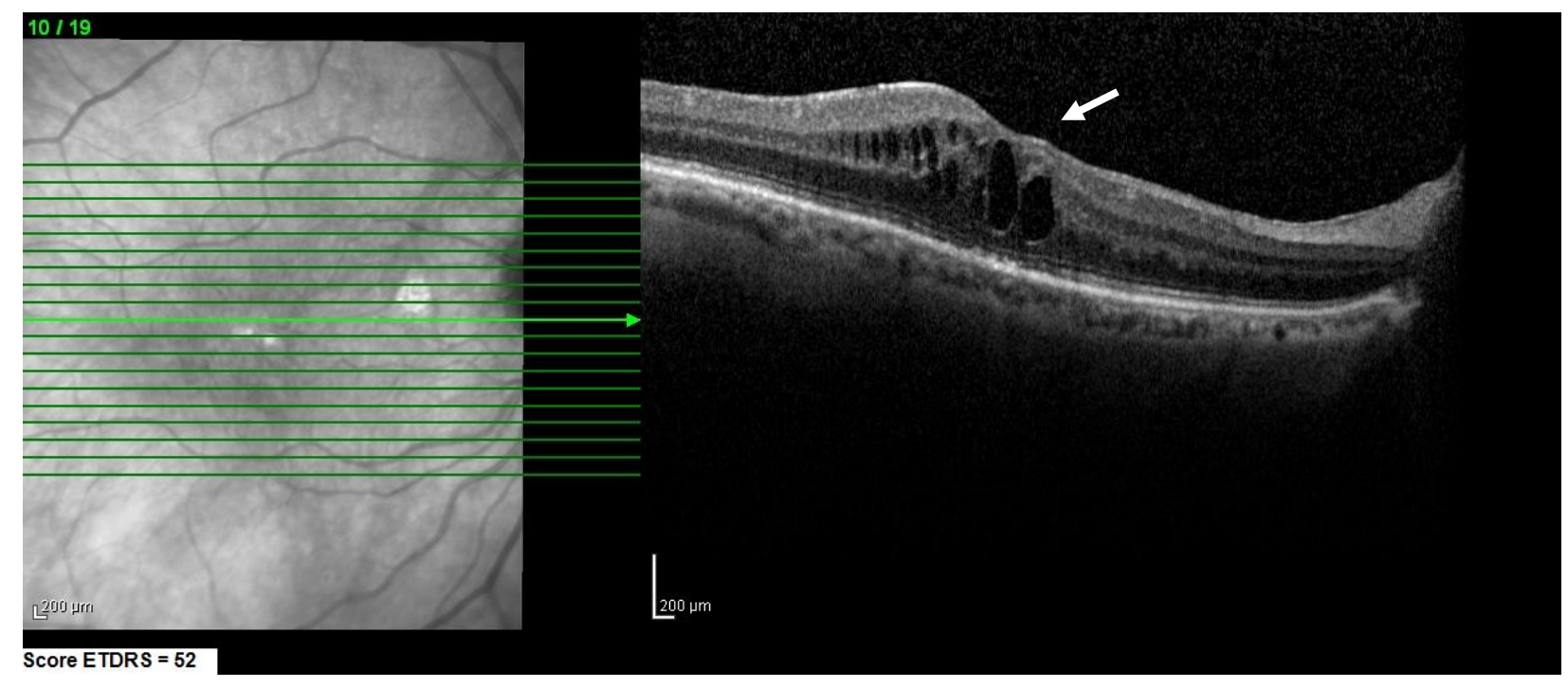

OCT 5 months after first injection

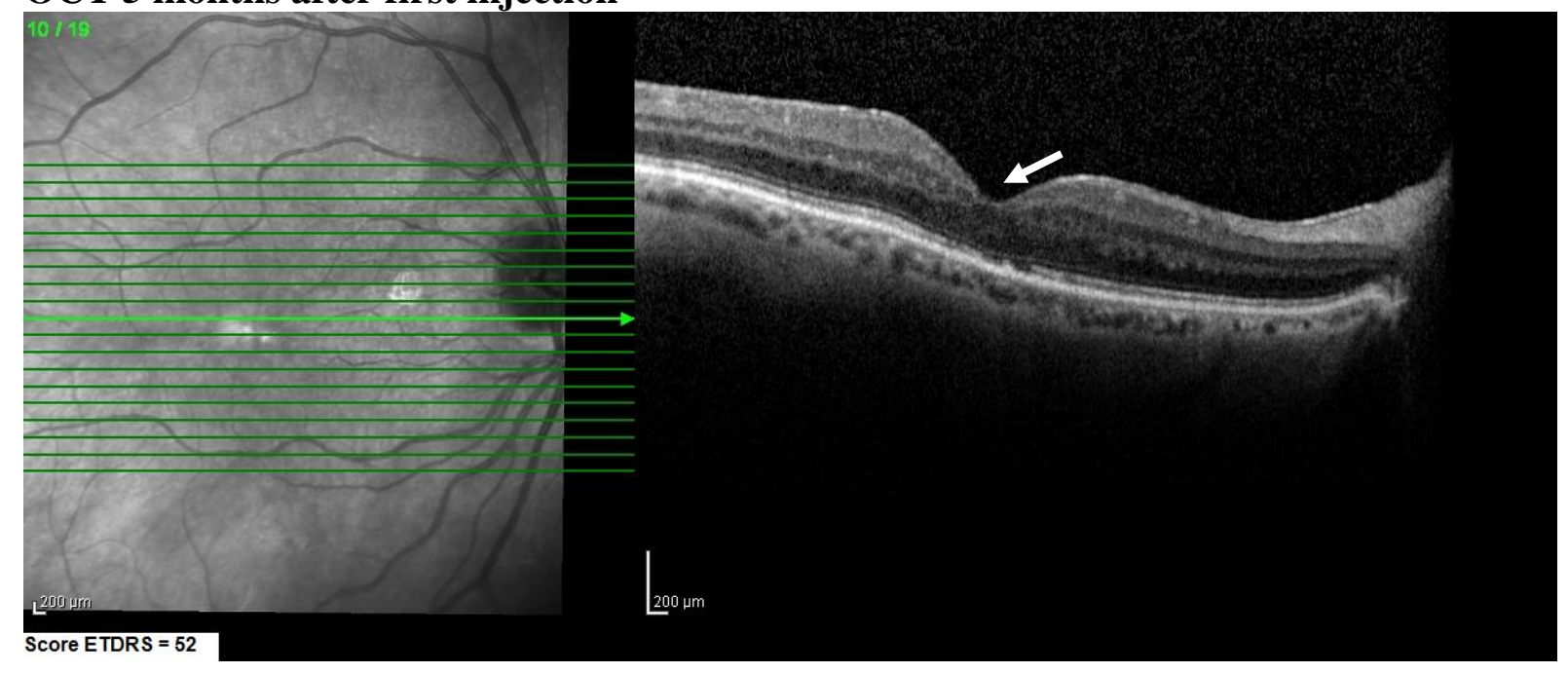

OCT 6 months after first injection 
FIGURES

Figure 2. Patient 5: macular OCT diagnosis, 3 months and 6 months after the first injection

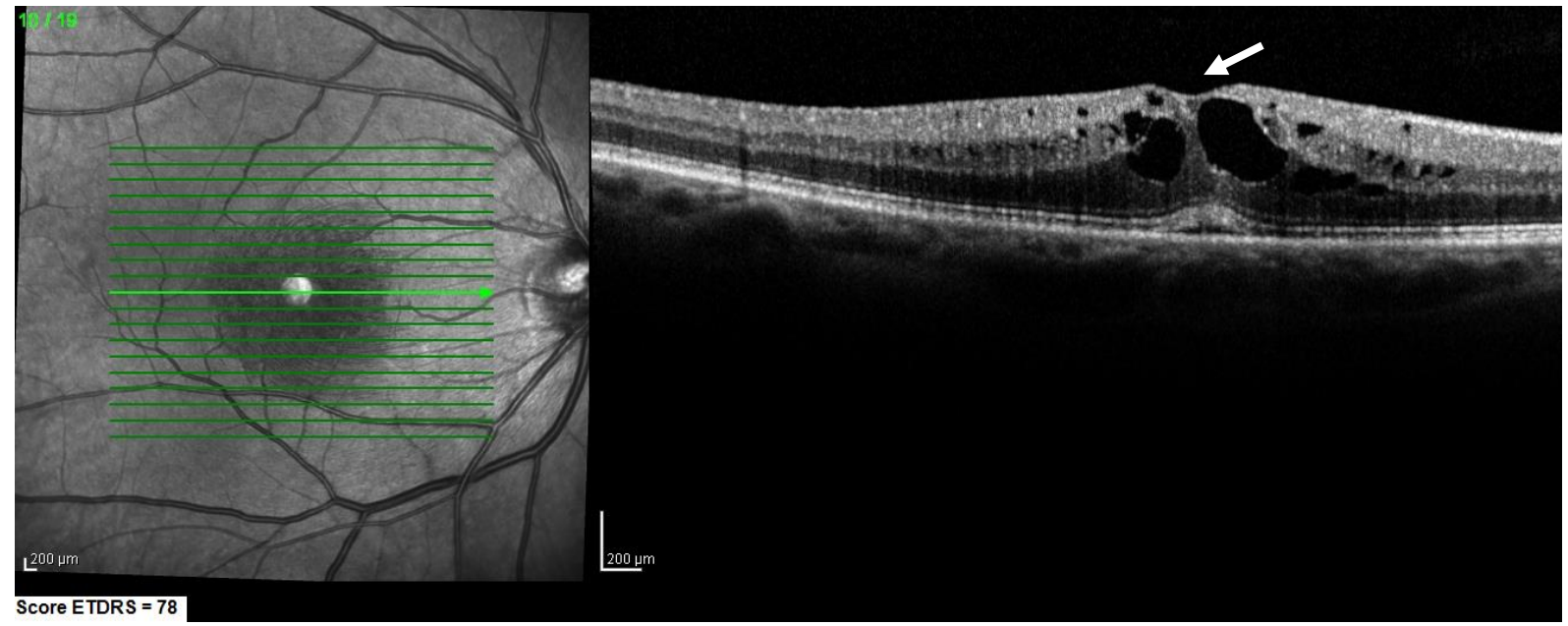

\section{OCT at diagnosis}

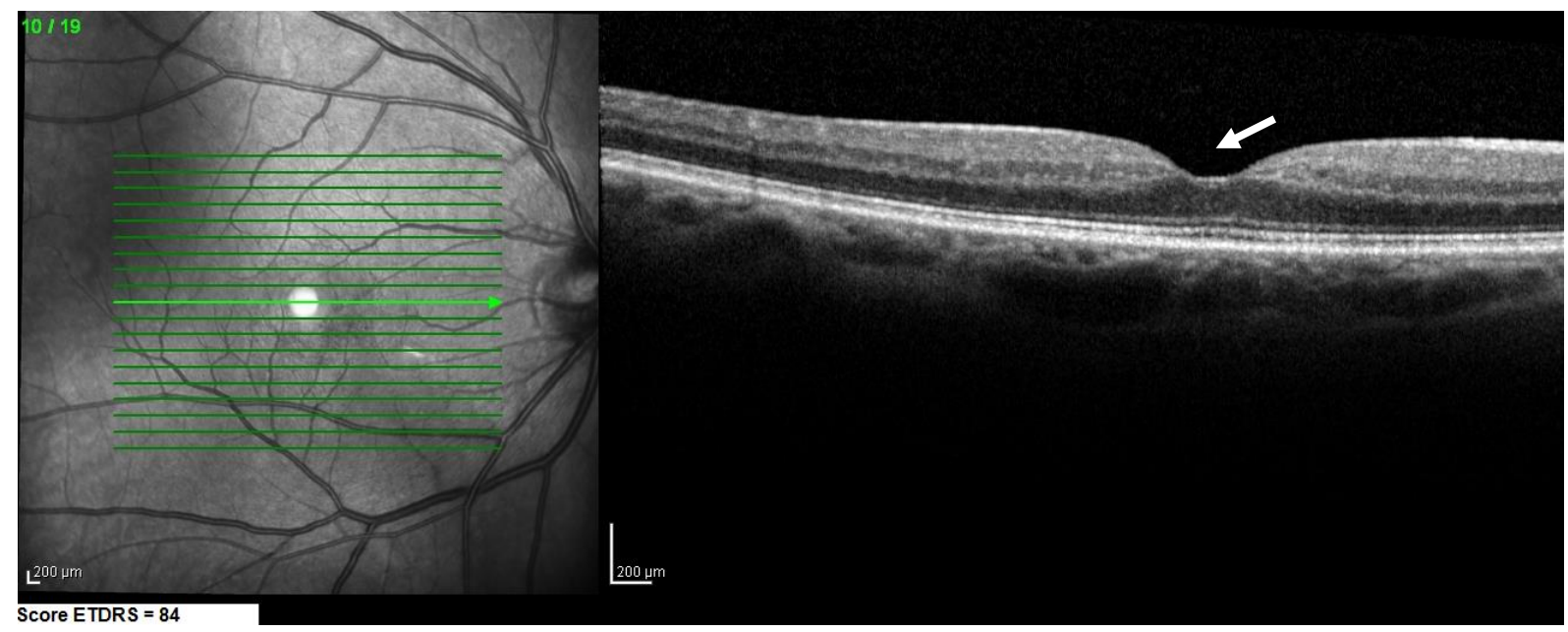

OCT 3 months after first injection

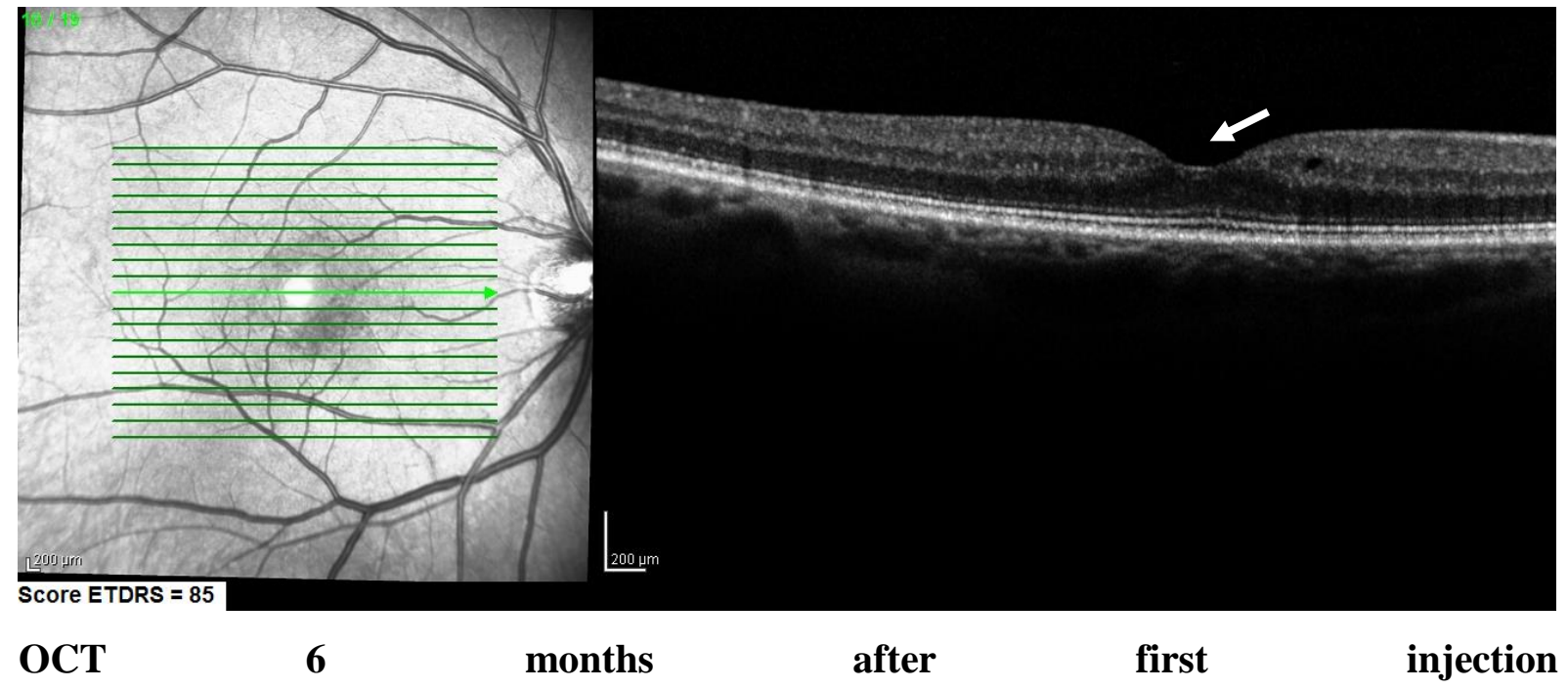


